The prevalence of domestic violence among pregnant women in Nigeria: a systematic review

Ms Joy Orpin, Institute for Health Research, University of Bedfordshire, Putteridge Bury, Hitchin Road, Luton LU2 8LE, Bedfordshire, UK. E-mail: joy.orpin@study.beds.ac.uk Dr Chris Papadopoulos, School of Health Care Practice \& Institute for Health Research, University of Bedfordshire, Putteridge Bury, Hitchin Road, Luton LU2 8LE, Bedfordshire, UK. E-mail: Chris.Papadopoulos@beds.ac.uk

Dr Shuby Puthussery*, School of Health Care Practice \& Institute for Health Research, University of Bedfordshire, Putteridge Bury, Hitchin Road, Luton LU2 8LE, Bedfordshire, UK. E-mail: shuby.puthussery@beds.ac.uk

*Corresponding author: Dr Shuby Puthussery, School of Health Care Practice \& Institute for Health Research, University of Bedfordshire, Putteridge Bury, Hitchin Road, Luton LU2 8LE, Bedfordshire, UK. Telephone: +44(0)1582743313 Fax number: +44(0)1582743918 


\begin{abstract}
Objective: To identify, appraise and synthesize research evidence on the prevalence of domestic violence (DV) among pregnant women in Nigeria.
\end{abstract}

Method: We conducted a systematic review of all published studies between April 2004 and June 2016. Comprehensive searches were conducted on electronic databases such as: PubMed, CINAHL, Global Health, MEDLINE, PsycINFO, Directory of Open Access Journals (DOAJ), Google Scholar and electronic libraries of the authors’ institution. Identified articles were screened in two stages against the inclusion criteria with titles and abstract screened first followed by full-text screening. Selected articles were assessed using the 'Guidelines for evaluating prevalence studies' and findings were synthesized narratively.

Results: Among 19 studies that met the inclusion criteria, two articles were excluded due to low methodological quality, and 17 articles were included in the review. The prevalence of DV during pregnancy in Nigeria ranged between $2.3 \%$ - 44.6\% with lifetime prevalence rates ranging between 33.1\%-63.2\%. Physical, sexual and financial abuses were the most frequent types of DV reported in this review. The most common perpetrators were husbands, as reported in 11 out of 17 studies. Pregnant women between the ages of 20-30 years were the most common victims of DV.

Conclusion: Our review provides evidence of relatively high prevalence of DV among pregnant women in Nigeria. The findings have important implications for stakeholders such as planners, policymakers, maternity care providers, and researchers in public health and social policy at national, regional, and international levels towards combating the issue.

Keywords: Domestic violence, pregnant women, prevalence, Nigeria. 


\section{The prevalence of domestic violence among pregnant women in Nigeria: a systematic}

\section{review}

\section{Introduction}

Domestic Violence (DV) is a significant public health issue worldwide. DV is defined as an episode or a series of controlling behavior, coercion and threats against people aged 16 and above by either current or past intimate partners and (or) family members despite sexual orientation or gender (United Kingdom (UK) Home Office, 2013). DV encompasses emotional, financial, sexual, psychological or physical abuse although it may not always be limited to these forms of abuse (United Nations Children's Emergency Fund (UNICEF), 2006; UK Home Office, 2013). The United Nations describes violence against women as acts of gender-based violence that is likely to cause or result in mental, sexual or physical harm and suffering to women in private or public life (United Nations, 2001). Approximately $35 \%$ (1 in 3) of women are abused globally and about 30\% of women in a relationship are victims of physical and/or sexual violence by an intimate or non-intimate partner (World Health Organization (WHO), 2016). It has also been indicated that over 38\% of women who are murdered worldwide are killed by their intimate partners (WHO, 2016). The lifetime prevalence of intimate partner violence (IPV) against women is shown to range internationally between 4\%-54\% with the lowest rates observed in Yokohama in Japan and the highest rates observed in Butajira in Ethiopia (Garcia-Moreno, Jansen, Ellsberg, Heise, \& Watts, 2006). The same study noted that higher rates of violence against women are observed in developing countries with strong links to traditional practices and rural settings (Garcia-Moreno et al., 2006). This corresponds with Alio, Daley, Nana, Duan, \& Salihu's (2009) findings showing a high prevalence of DV against women in two lower-middle income countries in the African region - Cameroon and 
Kenya - and four low-income countries - Malawi, Rwanda, Uganda, and Zimbabwe. The authors found that the overall mean lifetime prevalence of IPV across these countries was approximately 39.8\% with Ethiopia and Uganda having the lowest and highest rates of $30.2 \%$ and $60.9 \%$ respectively (Alio et al., 2009).

DV during pregnancy poses significant risks to both the woman and her unborn child. Victims of DV are prone to increased rates of sexually transmitted infections, premature births, miscarriages, unintended pregnancies, preeclampsia, vaginal bleeding, stillbirth, and low birth weight (Cook \& Bewley, 2008; Garcia, Soria, \& Hurwitz, 2007; Sharps, Laughon, \& Giangrande, 2007; WHO, 2016). Mental health conditions such as postpartum depression, homicide and suicidal thoughts, anxiety, trauma and eating disorders are reported among women who are victims of abuse either before or during pregnancy (Beydoun, Beydoun, Kaufman, Lo, \& Zonderman, 2012; Certain, Mueller, Jagodzinski, \& Fleming, 2008; WHO, 2016). The consequences of DV and the low antenatal care seeking behavior among victims of DV are likely to increase infant and maternal morbidity and mortality rates (Sarkar, 2013).

Researchers continue to disagree about whether DV prevalence increases, decreases, or remains about the same during pregnancy (Bailey, 2010). There are also wide variations in prevalence rates internationally. For example, a study among 19 countries found the prevalence rate of IPV during pregnancy as ranging between 2.0\% to 31.5\% (Devries et al., 2010). The authors assert that Latin American and African countries have higher rates of IPV during pregnancy compared to European and Asian countries (Devries et al. 2010). Existing research has consistently indicated a high prevalence of DV in pregnancy among women in African countries (Alio et al., 2009; Shamu, Abrahams, Temmerman, Musekiwa, \& Zarowsky, 2011; Uthman, Lawoko, \& Moradi, 2009). A meta-analysis conducted by 
Shamu et al. (2011) has estimated the prevalence of IPV during pregnancy in African countries as ranging from 2\%-57\% (Shamu et al., 2011). A cross-sectional clinic-based survey of post-natal women conducted in Zimbabwe reported the prevalence of IPV during pregnancy to be 63.1\% approximately (Shamu et al., 2013). In Nigeria, which is the most populated country in Sub-Saharan Africa, previous studies have reported a lifetime prevalence of physical abuse against women as $52.1 \%$ in the South-south zone, $31.0 \%$ in North-central, 29.6\% in South-East, 28.9\% in the South-West, 19.7\% in the North-East and 13.1\% in the North-West zone (National Population Commission, 2009). A more recent study reported the lifetime prevalence of spousal violence among cohabiting and married women in the Southwestern region of Nigeria as $47.3 \%$ approximately (Alo, Odusina, \& Babatunde, 2012).

Although studies that provide relevant insights about the prevalence of DV among pregnant women are emerging, the problem remain largely unrecognized in the country, and it would seem that the individual studies do not provide sufficient evidence on their own to warrant appropriate action. This review aims to systematically appraise and synthesize the published literature on prevalence and types of DV among pregnant women living in Nigeria to inform policy, practice and future research.

\section{Methods}

This study employed a systematic review design to identify, assess, and synthesize primary research evidence on the prevalence of DV among pregnant women in Nigeria.

\section{Inclusion criteria}

The inclusion criteria are presented in detail in Table 1. We included published primary and secondary empirical studies conducted in Nigeria reporting quantitative prevalence data on 
Table 1: Inclusion Criteria

\section{Inclusion criteria}

- Quantitative primary and secondary empirical studies reporting DV prevalence data

- Conducted in Nigeria

- Participants were pregnant women

- Published in English language

- $\quad$ Reported in peer-reviewed sources

- $\quad$ Published between 2004-2016

DV against women during pregnancy. Only studies published in English in peer-reviewed journal articles between April 2004 and June 2016 were included. Studies that did not meet our quality threshold (see below) were excluded from the final analysis.

\section{Data sources and search strategy}

Various electronic databases were searched to identify relevant primary studies. These databases included: PubMed, CINAHL, Global Health, MEDLINE, PsycINFO, Directory of Open Access Journals (DOAJ), Google Scholar and the electronic libraries of the authors’ institution. A combination of text words and MeSH terms were used such as: (Nigeri* OR “West Africa” OR “Sub-Saharan Africa” OR Africa) AND (pregnan* OR gestati* OR antenatal) AND (“domestic violence” OR “intimate partner violence” OR "family violence” OR “spousal violence” OR abuse* OR batter* OR violen*). We additionally searched key journals from the region such as the African Journal of Reproductive Health, African Journals Online, and Annals of African Medicine for potentially relevant articles not indexed in 
electronic databases. Bibliographies of all full text articles that met the inclusion criteria were inspected and authors were contacted to locate any additional relevant studies.

\section{Screening strategy and quality appraisal}

The screening was conducted in 2 stages. The first stage involved screening the titles and abstracts against the inclusion criteria. Following stage 1 screening, full texts of all included articles were retrieved. In stage 2, a comprehensive assessment of the full-text articles was undertaken. After stage 2 assessment, the selected studies were critically appraised for their methodological quality using ‘Guidelines for evaluating prevalence studies’ (Boyle, 1998) which consists of 8 items for rating methodological quality of prevalence studies. Studies that scored 2 points or less were viewed to be of very low methodological quality and hence were excluded from the analysis.

\section{Data extraction}

Data from all the included studies were extracted using a spreadsheet created in Microsoft Excel. The headings used for the data extraction were: authors, year of publication, study aims and objectives, study design, study setting and duration, sample size and response rate, sampling method, data collection method, DV prevalence data, types of violence, and the reported perpetuators.

\section{Data analysis}

Findings were synthesized using a narrative approach as we were unable to conduct metaanalysis due to the heterogeneity of the selected studies. In the narrative analysis, structured data summaries were developed, elaborated upon and put into context (Centre for Reviews and Dissemination (CRD), 2009; Harden et al., 2004). 


\section{Ethics Approval}

The review was approved by the University of Bedfordshire's Institute for Health Research Ethics Committee.

\section{Results}

\section{Study selection}

The results of the search and study selection are shown in Figure 1 [INSERT FIGURE 1 HERE]. The search process produced 1,384 titles and 902 records were retrieved after duplicates were removed. Following title and abstract screening, 88 articles were selected for full text screening and 69 articles were excluded further due to discordance with the inclusion criteria. Finally, 19 articles that met the inclusion criteria were subjected to quality appraisal. Four studies scored eight points, five studies scored seven, three studies scored six; three studies scored five; two studies scored four, and two studies scored two points. The two studies that scored two points on quality appraisal (Ameh \& Abdul, 2004; Ameh, Shittu, \& Abdul, 2008) were subsequently excluded from analysis. Finally 17 studies were synthesized in this review. The results of the quality appraisal exercise are presented in Table 2 [INSERT TABLE 2 HERE].

\section{Study characteristics}

All the studies were conducted in Nigeria in settings spread across the country's six geopolitical zones. Four studies were conducted in the North-Central region, four in the South-West region, three in the South-South region and three in the North-West region, two in the South-East region. One study covered both South-South and North-East regions. A summary of study characteristics are presented in Table 3 [INSERT TABLE 3 HERE]. 
Fifteen studies were cross-sectional studies while two (Ezechi et al., 2004; Abasiubong et al., 2010) did not clearly state the study design used. The duration of the studies ranged between one month (Adesina et al., 2011; Envuladu et al., 2012; Fawole et al., 2010; Iliyasu et al., 2013) and eleven months (Awusi et al., 2009).

The overall sample size in individual studies ranged from 202 (Envuladu et al., 2012) to 7,888 (Ansari et al., 2016). Among the nine studies that reported sampling methods, two employed simple random sampling (Fawole et al., 2008; Umeora et al., 2008), three used systematic random sampling (Abasiubong et al., 2010; Adesina et al., 2011; Arulogun \& Jidda, 2011) while one study used stratified random cluster sampling (Ansari et al., 2016). Two studies used systematic sampling methods (Envuladu et al., 2012; Iliyasu et al., 2013) and one study used a non-random sampling method (Gyuse et al., 2009). Sixteen studies were conducted in hospital settings expect one, (Ansari et al., 2016) was conducted in the community.

\section{Prevalence of domestic violence in Nigeria}

The prevalence of DV during current pregnancy ranged from 2.3\% (Fawole et al., 2008) to 44.6\% (Onoh et al., 2013). One study (Olagbuji et al., 2010) found prevalence rates of 15.5\%, $16.3 \%$ and $17.1 \%$ during the first, second and third trimesters of pregnancy respectively. Another study reported 28.9\% prevalence of DV during previous pregnancy (Envuladu et al., 2012). Three studies reported the prevalence of DV one year before the current pregnancy as $14.2 \%, 31.8 \%$ and 43.5\% respectively (Fawole et al., 2008; Fawole et al., 2010; Olagbuji et al., 2010). Five studies reported both lifetime and current prevalence of DV among pregnant women (Abasiubong et al., 2011; Adesina et al., 2011; Arulogun \& Jidda, 2011; Envuladu et al., 2012; Gyuse et al., 2009). The lifetime prevalence ranged from 63.2\% (Abasiubong et 
al., 2010) to 33.1\% (Adesina et al., 2011). The prevalence rates reported in the included studies are presented in Table 3.

Pregnant women between the ages of 20-30 years were the most common victims of DV reported in studies (Abasiubong et al., 2010; Ameh et al., 2009; Arulogun \& Jidda, 2011; Awusi et al., 2009; Ezechi et al., 2004; Umeora et al., 2008) followed by women who were aged less than 20 years.

\section{Types of DV among pregnant women and the main perpetrators}

All the studies, except one (Gyuse et al., 2009) highlighted the types of violence reported by pregnant women. Physical, sexual and financial abuse were the most frequently reported forms of abuse across the studies. Other types of violence included psychological, verbal and other threats of abuse. A summary of the types of abuse reported in the included studies is presented in Table 4 [INSERT TABLE 4 HERE].

The perpetrators of DV were reported in all the studies except two (Gyuse et al., 2009; Umeora et al., 2008). Husbands were reported as the most common perpetrators of DV during pregnancy in 11 out of the 17 studies. Other perpetrators included co-wives, mother in-laws and other relatives of the husband (Ameh et al., 2009; Ashimi \& Amole, 2015; Efetie \& Salami, 2008; Ezechi et al., 2004; Olagbuji et al., 2010).

\section{Discussion}

The current review was undertaken to synthesize the evidence on DV prevalence in pregnancy in Nigeria. Despite a comprehensive search, the authors did not find any other systematic reviews focusing on this issue from Nigeria or the sub-Saharan African region. Our review showed that a number of studies have assessed the prevalence of DV among 
pregnant women in Nigeria and majority of the studies (10) were of fairly good methodological quality with a score of 5-8 on an 8 p-point assessment scale. The prevalence of DV during current pregnancy reported in studies included in this review showed wide variations ranging from 2.3\% (Fawole et al., 2008) - 44.6\% (Onoh et al., 2013). Previous studies have also reported similar range of prevalence from African countries. For example, Shamu et al. (2011) reported IPV prevalence during pregnancy to be between $2.3-57.1 \%$ in African countries. Another study reported a 63.1\% prevalence of IPV during current pregnancy in Kenya (Shamu et al., 2013). The differences in prevalence rates across studies included in our review could be attributed to the variations in the methodology and the types of DV assessed. It would seem that some studies with low prevalence rates had a larger number of women who had concerns about participating in the study (Fawole et al., 2008). This might imply that these women may not have fully disclosed their experience of DV during pregnancy due to fear of further victimization from the perpetrators.

Our review, however, indicates relatively high prevalence rates in most of the included studies which would imply that the prevalence of DV during pregnancy among pregnant women is of common occurrence in Nigeria. One of the potential reasons for this high prevalence could be the patriarchal nature of the Nigerian society. According to the feminist theorists, a patriarchal society is believed to encourage male dominance by exercising control over women that could result in violence against women (Jewkes, 2002). Consequently, many women are believed to accept wife beating and justify violence perpetrated against them (Butovskaya, 2012; Jewkes, 2002; Odimegwu \& Okengbo, 2003).

Although two studies included in this review reported changes in DV prevalence at different stages of pregnancy, the findings were inconsistent (Adesina et al., 2011; Iliyasu et al. 2013). While one study reported no significant changes in DV prevalence throughout the different 
stages of pregnancy (Adesina et al., 2011), the other study found an increase in DV prevalence as pregnancy progressed (Iliyasu et al., 2013). Previous research has documented a higher prevalence of DV during the period just before pregnancy with a subsequent reduction as the pregnancy progressed (Gomez \& Speizer, 2010; Lukasse et al., 2014; Roelens, Verstraelen, Egmond, \& Temmerman, 2008). It has also been indicated that women tend to disclose their experiences of DV more at the early stages of pregnancy compared to the later stages of pregnancy and the postpartum period (Keeling \& Mason, 2011).

As came up in our review, pregnant women aged between 20-30 years are at a higher risk of DV compared to other age groups. As women tend to be mostly sexually active during this period, they tend to indulge more in intimate relationships which could potentially increase their vulnerability and risk of abuse from intimate partners (Fonck, Els, Kidula, NdinyaAchola, \& Temmerman, 2005; Rivara et al., 2009). Similar findings have been reported by Devries et al. (2010) in a study conducted across 19 countries. They found that the highest proportion of abuse happened to pregnant women aged between 15-35 years. In some African cultures, it is acceptable for young women to have much older male partners that often leads to imbalance of power and authority in the relationship making young women vulnerable to abuse (Dunkle, 2007). It has also been argued that as women become 35 years and over, their social status is likely to increase which in turn reduces their vulnerability to violence (Alo et al., 2012). As couples live together, they may also develop a better understanding of each other which might reduce the risk of violence (Alo et al., 2012).

The most frequently reported types of DV in our review were physical, sexual and financial abuse regardless of whether it is current pregnancy or lifetime occurrence. This finding is consistent with those reported by Matseke, Peltzer and Mlambo (2012). The authors identified physical, sexual, and financial abuse as the most predominant types of abuse 
among pregnant women in South Africa. The cultural acceptability of wife beating in some African countries could be one of the reasons for the high prevalence of physical abuse (Rani, Bonu, \& Diop-Sidibe, 2004; Uthman et al., 2009). Some African women tend to perceive violence inflicted on them as a way of their partners' coping with the challenges and frustrations of war and conflict (Horn, Puffer, Roesch, \& Lehmann, 2014), punishing them for wrong-doings in their own right, or even as an expression of love (Jewkes, 2002).

Sexual violence was found to be commonly prevalent in our review. Similar findings have been reported by other researchers (Makayoto, Omolo, Kamweya, Harder, \& Mutai, 2013; Sarkar, 2008). Sexual violence could result from the cultural assumption that women are the property of their husbands and are expected to always submit to husband's wishes in sexual matters (Jewkes, 2002; Arisi \& Oromareghake, 2011; Makama, 2013). Financial abuse could be partly stemming from the fact that most women participants in the included studies had a low level of education that can impact upon their autonomy in financial decisions. Other researchers have argued that pregnant women in South Africa experience financial abuse because they have fewer resources increasing their dependence on husbands (Shilubane \& Khoza, 2014). Pregnant women with low levels of education and/ or no source of livelihood are more likely to be vulnerable to experience violence (Heaman, 2005; James, Brody, \& Hamilton, 2013).

Husbands and boyfriends were the most common perpetrators of violence as came up in our review. This is consistent with findings that report intimate partners as the common perpetrators of DV against women (Makayoto et al., 2013). Other family members like inlaws and step-sons were the next commonly reported perpetrators of DV. Patriarchy that assumes male dominance and power imbalance between men and women could offer possible 
explanations as to why men in general tend to be the most commonly reported perpetrators of DV (Jewkes, 2002).

\section{Limitations}

This review has certain limitations. Although a systematic search was conducted to identify all the relevant studies, our restriction to studies published in English might have led to exclusion of relevant papers published in local languages. This is, however, expected to be minimal as English is the official language of the country. Due to limited resources, we were unable to explore any potential publication bias resulting from exclusion of unpublished studies or findings reported in grey literature. In order to focus on most recent studies, we included only studies published after 2004 which might have resulted in exclusion of potentially relevant older studies. As mentioned before, a narrative approach was undertaken for this review as variations in the methods and the wide differences in prevalence rates among included studies made the review inappropriate for meta-analysis (CRD, 2009). The selected studies were from five of the six geopolitical zones and no relevant studies were found from the Northeast zone.

\section{Conclusion}

Our review provides evidence of relatively high prevalence rates of DV among pregnant women in Nigeria. The findings have important implications for a range of stakeholders such as planners, policymakers, maternity care providers, and researchers in public health and social policy at national, regional, and international levels towards combating the issue of DV in pregnancy. Although there have been several attempts internationally to address the issue, our findings point to the need for more concerted country level action in Nigeria involving interventions at various levels such as home, health facilities, and the wider community. The 
findings also point out a number of areas for future research. Although there have been studies about the prevalence of DV in pregnancy, there is a still a dearth of nationally representative data to inform concerted action to tackle the issue. There is also a need for more in-depth understanding of the associated cultural, social and environmental factors, including drivers for behavior change. Qualitative studies can be of great value in this respect. Evidence about any existing interventions to combat the issue in the country also appears to be very limited. Nigeria accounts for one of the highest rates of maternal deaths globally; hence eliminating high risk factors for maternal ill health such as DV in pregnancy is imperative to improve maternal health.

\section{References}

Abasiubong, F., Abasiattai, M. A. Bassey, A. E., \& Ogunsemi, O. O. (2010). Demographic risk factors in domestic violence among pregnant women in Uyo, a community in the Niger Delta region, Nigeria. Health Care for Women International, 31(10), 891-901.

Adesina, O., Oyugbo, I., \& Olubukola, A. (2011) Prevalence and pattern of violence in pregnancy in Ibadan, South-west Nigeria. Journal of Obstetrics and Gynecology, 31(3), 232236.

Alio, P. A., Daley, M. E, Nana, N. P., Duan, J., \& Salihu, M. H. (2009). Intimate partner violence and contraception use among women in Sub-Saharan Africa. International Journal of Gynecology and Obstetrics, 107(1), 35-38.

Alo, A. O., Odusina, K. E., \& Babatunde, G. (2012). Spousal violence in Southwest Nigeria: Prevalence and correlates. Journal of Women's Health Care, 1(2), 1-8. 
Ameh, N., \& Shittu, S.O. (2004). Prevalence of domestic violence amongst pregnant women in Zaria, Nigeria. Annals of African Medicine, 3(1), 4-6.

Ameh, N., Shittu, S. O., \& Abdul, M. A. (2009). Obstetric outcome in pregnant women subjected to domestic violence. Nigerian Journal of Clinical Practice, 12(2), 179-181.

Ameh, N., Shittu, S.O., \& Abdul, M. A. (2008). Risk scoring for domestic violence in pregnancy. Nigerian Journal of Clinical Practice, 11(1), 18-21.

Ansari, U., Cobham, B., Etim, M. E., Ahamad, M. H., Owan, O. N., Tijani, Y., ...\& Andersson, N. (2015). Insights into intimate partner violence in pregnancy: Findings from a cross-sectional study in two states in Nigeria. Violence against Women, 1-13.

Arisi, R. O., \& Oromareghake, P. (2011). Cultural violence and the Nigerian woman. International Multidisciplinary Journal, 5(4), 369-381.

Arulogun, O. S., \& Jidda, K. A. (2010). Experiences of violence among pregnant women attending antenatal clinics in selected hospitals in Abuja, Nigeria. Sierra Leone Journal of Biomedical Research, 3(1), 43-48.

Ashimi, A. O., \& Amole, T. G. (2015). Prevalence and predictors for domestic violence among pregnant women in a rural community Northwest, Nigeria. Nigerian Medical Journal : Journal of the Nigeria Medical Association, 56(2), 118-121.

Awusi, V.O., Okeleke, V.O., \& Ayanwu, B. E. (2009). Prevalence of domestic violence during pregnancy in Oleh, a suburban Isoko community, Delta State, Nigeria. Benin Journal of Postgraduate Medicine, 11(1), 15-18. 
Bailey, B.A. (2010). Partner violence during pregnancy: prevalence, effects, screening, and management. International Journal of Women's Health 10; (2), 183-197.

Beydoun, H. A., Beydoun, M. A., Kaufman, J. S., Lo, B., \& Zonderman, A. B. (2012). Intimate partner violence against adult women and its association with major depressive disorder, depressive symptoms and postpartum depression: A systematic review and metaanalysis. Social Science \& Medicine, 75(6), 959-975.

Boyle, H. M. (1998). Guidelines for evaluating prevalence studies. Evidence Based Mental Health, 1(2), 37-39.

Butovskaya, L. M. (2012). Wife-battering and traditional methods of its control in contemporary Datoga pastoralists of Tanzania. Journal of Aggression, Conflict and Peace Research, 4(1), 28-44.

Centre for Reviews and Dissemination (2009). Systematic reviews: CRD's guidance for undertaking reviews in health care. University of York: Centre for Reviews and Dissemination.

Certain, H. E., Mueller, M., Jagodzinski, T., \& Fleming, M. (2008). Domestic abuse during the previous year in a sample of postpartum women. Journal of Obstetric, Gynecologic \& Neonatal Nursing, 37 (1), 35-41.

Cook, J., \& Bewley, S. (2008). Acknowledging a persistent truth: Domestic violence in pregnancy. Journal of the Royal Society of Medicine, 101(7), 358-363.

Devries, M. K., Kishor, S., Johnson, H., Stöckl, H., Bacchus, J. L., Garcia-Moreno, C., \& Watts, C. (2010). Intimate partner violence during pregnancy: analysis of prevalence data from 19 countries. Reproductive Health Matters, 18(36), 158-170. 
Dunkle, K. L., Jewkes, R., Nduna, M., Jama, N., Levin, J., Sikweyiya, Y., \& Koss, M. P. (2007). Transactional sex with casual and main partners among young South African men in the rural Eastern Cape: Prevalence, predictors and associations with gender-based violence. Social Science and Medicine, 65(6), 1235-1248.

Efetie, E. R., \& Salami, H. A. (2009). Domestic violence on pregnant women in Abuja, Nigeria. Journal of Obstetrics and Gynecology, 27(4), 379-382.

Envuladu, E. A., Chia, L., Banwat, E. A., Lar, A. L., Agbo, A. H., \& Zoakah, I. A. (2012). Domestic violence among pregnant women attending antenatal clinic in a PHC facility in Jos north LGA Plateau State Nigeria. Journal of Medical Research, 1(5). 63-68.

Ezechi, O. C. 1., Kalu, B. K 1., Ezechi, L. O., Nwokoro, C. A., Ndububa, V. I., \& Okeke, G. C. E. (2004). Prevalence and pattern of domestic violence against pregnant Nigerian women`, Journal of Obstetrics and Gynecology, 24(6), 652-656.

Fawole, A. O., Hunyinbo, I. K., \& Fawole, O. I. (2008). Prevalence of violence against pregnant women in Abeokuta, Nigeria. Australian and New Zealand Journal of Obstetrics and Gynecology, 48(4), 405-414.

Fawole, I. O., Abass, L. W. A., \& Fawole, A. O. (2010). Prevalence of violence against pregnant women in Ibadan, Nigeria. African Journal of Medicine and Medical Sciences, 39(4), 293-303.

Fonck, K., Els, L, Kidula, N., Ndinya-Achola, J., \& Temmerman, M. (2005). Increased risk of HIV in women experiencing physical partner violence in Nairobi, Kenya', AIDS and Behavior, 9(3), 335-339. 
Garcia, L., Soria, C., \& Hurwitz, L. E. (2007). Homicides and intimate partner violence: A literature review. Trauma Violence Abuse, 8(4), 370-383.

Garcia-Moreno, C., Jansen, A. F. M. H., Ellsberg, M., Heise, L., \& Watts, C. H. A. (2006). Prevalence of intimate partner violence: findings from the WHO multi-country study on women`s health and domestic violence. The Lancet, 368(9543), 1260-1269.

Gomez, M. A., \& Speizer, S. I. (2010). Community-level intimate partner violence and the circumstances of first sex among young women from five African countries. Reproductive Health, 7(1), 1-8.

Gyuse, A. N. I., Ushie, A. P., \& Etukidem, A. (2009). Prevalence of domestic violence among antenatal women attending a Nigerian hospital. Nigerian Journal of Medicine, 18(4), 375-379.

Harden, A., Garcia, J, Oliver, S., Rees, R., Shepherd, J., Brunton, G., \& Oakley, A. (2004). Applying systematic review methods to studies of people’s views: An example from public health research. Journal of Epidemiology and Community Health, 58, 794-800.

Heaman, M. I. (2005). Relationships between physical abuse during pregnancy and risk factors for preterm birth among women in Manitoba. Journal of Obstetrics, Gynecologic and Neonatal Nursing, 34, 721-73.

Horn, R., Puffer, E. S., Roesch, E., \& Lehmann, H. (2013). Women`s perceptions of effects of war on intimate partner violence and gender roles in two post-conflict West African Countries: consequences and unexpected opportunities. Conflict and Health, 8(12). 
Iliyasu, Z., Abubakar, I. S., Galadanci, S. H., Hayatu, Z., \& Aliyu, M. H. (2013). Prevalence and risk factors for domestic violence among pregnant women in Northern Nigeria. Journal of Interpersonal Violence, 28(4), 868-883. Doi: 10.1177/0886260512455872

James, L., Brody, D., \& Hamilton Z. (2013). Risk factors for domestic violence during pregnancy: a meta-analytic review. Violence and Victims. 28(3), 359-80.

Jewkes, R. (2002). Intimate partner violence: causes and prevention. The Lancet, 359(9315), 1423-1429.

Keeling, J., \& Mason, T. (2011). Postnatal disclosure of domestic violence: Comparison with disclosure in the first trimester of pregnancy. Journal of Clinical Nursing, 20(1-2), 103-110.

Lukasse, M., Schroll, A., Ryding, E. L., Campbell, J., Karro, H., Kristjansdottir H., ...\& Schei, B. (2014). Prevalence of emotional, physical and sexual abuse among pregnant women in six European countries. Acta Obstetricia et Gynecologica Scandinavica, 93(7), 669-677.

Makama, G. A. (2013). Patriarchy and gender inequality in Nigeria: The way forward. European Scientific Journal, 9(17), 115-44.

Makayoto, A. L., Omolo, J., Kamweya, M. A., Harder, S. V., \& Mutai, J. (2013). Prevalence and associated factors of intimate partner violence among pregnant women attending Kisumu district hospital, Kenya. Maternal Child Health Journal, 17(3), 441-447.

Matseke, G., Peltzer, K., \& Mlambo, G. (2012). Partner violence and associated factors among pregnant women in Nkangala district, Mpumalanga. South African Journal of Obstetrics and Gynecology, 18(3), 77-81. 
National Population Commission (2009). Nigerian Demographic and Health Survey 2008.

Retrieved from

http://www.unicef.org/nigeria/ng_publications_Nigeria_DHS_2008_Final_Report.pdf

Odimegwu, C., \& Okengbo, C. N. (2003). Gender role ideologies and prevalence of violence against women in Imo State, Nigeria. Anthropologist, 5 (4), 225-236.

Olagbuji, B., Ezeanochie, M. Ande, A., \& Ekaete, E. (2010). Trends and determinants of pregnancy-related domestic violence in a referral center in southern Nigeria. International Journal of Gynecology and Obstetrics, 108(2), 101-103.

Onoh, R. C., Umeora, O. U. J., Ezeonu, P. O., Onyebuchi, A. K., Lawani, O. L., \& Agwu, U. M. (2013). Prevalence, pattern and consequences of intimate partner violence during pregnancy at Abakaliki Southeast Nigeria. Annals of Medical and Health Sciences Research, 3(4), 484-491.

Rani, M., Bonu, S., \& Diop-Sidibe, N. (2004). Beating among men and women in seven Sub-Saharan African Countries. African Journal of Reproductive Health, 8(3), 116-136.

Rivara, F. P, Anderson, M. L., Fishman, P., Reid, R. J., Bonomi, A. E., Carrell, D., \& Thompson, R. S. (2009). Age, period, and cohort effects on intimate partner violence. Violence and Victims, 24(5), 627-638.

Roelens, K., Verstraelen, H., Egmond, V. K., \& Temmerman, M. (2008). Disclosure and health-seeking behavior following intimate partner violence before and during pregnancy in Flanders, Belgium: A survey surveillance study. European Journal of Obstetrics and Gynecology and Reproductive Biology, 137(1), 37-42. 
Sarkar, N. N. (2008). The impact of intimate partner violence on women's reproductive health and pregnancy outcome. Journal of Obstetrics and Gynecology, 28(3), 266-271.

Sarkar, N. N. (2013). The cause and consequence of domestic violence on pregnant women in India. Journal of Obstetrics and Gynecology, 33, (3), 250-253.

Shamu, S., Abrahams, N., Temmerman, M., Musekiwa, A., \& Zarowsky, C. (2011). A systematic review of African studies on intimate partner violence against pregnant women: prevalence and risk factors. PLoS ONE, 6(3), e17591.

Shamu, S., Abrahams, N., Zarowsky, C., Musekiwa, A., Shefer, T., \& Temmerman, M. (2013). Intimate partner violence during pregnancy in Zimbabwe: A cross-sectional study of prevalence, predictors and associations with HIV. Tropical Medicine and International Health, 18(6), 696-711.

Sharps, P.W., Laughon, K., \& Giangrande, S. K. (2007). Intimate partner violence and the childbearing year: Maternal and infant health consequences. Trauma Violence Abuse, 8(2), 105-116.

UK Home Office (2013). Information for local areas on the change to the definition of domestic violence and abuse. Retrieved from https://www.gov.uk/government/uploads/system/uploads/attachment_data/file/142701/guideon-definition-of-dv.pdf

Umeora, O. U. J., Dimejesi, B. I., Ejikeme, B. N., \& Egwuatu, V. E. (2008). Pattern and determinants of domestic violence among prenatal clinic attendees in a referral center, Southeast Nigeria. Journal of Obstetrics and Gynecology, 28(8), 769-774. 
United Nations (2001). Violence against women: An issue of gender. Retrieved from http://www.womensaid.ie/download/pdf/violence_against_women_an_issue_of_gender.pdf

United Nations Children‘s Funds (2006). Behind closed doors the impact of domestic violence on children. Retrieved from

http://www.unicef.org/protection/files/BehindClosedDoors.pdf

Uthman, A. O., Lawoko, S., \& Moradi, T. (2009). Factors associated with attitudes towards intimate partner violence against women: A comparative analysis of 17 sub-Saharan countries. BMC International Health and Human Rights, 9(14).

World Health Organization (2016). Media center: Violence against women. Retrieved from http://www.who.int/mediacentre/factsheets/fs239/en/ 


Figure 1: Flow diagram illustrating study selection process

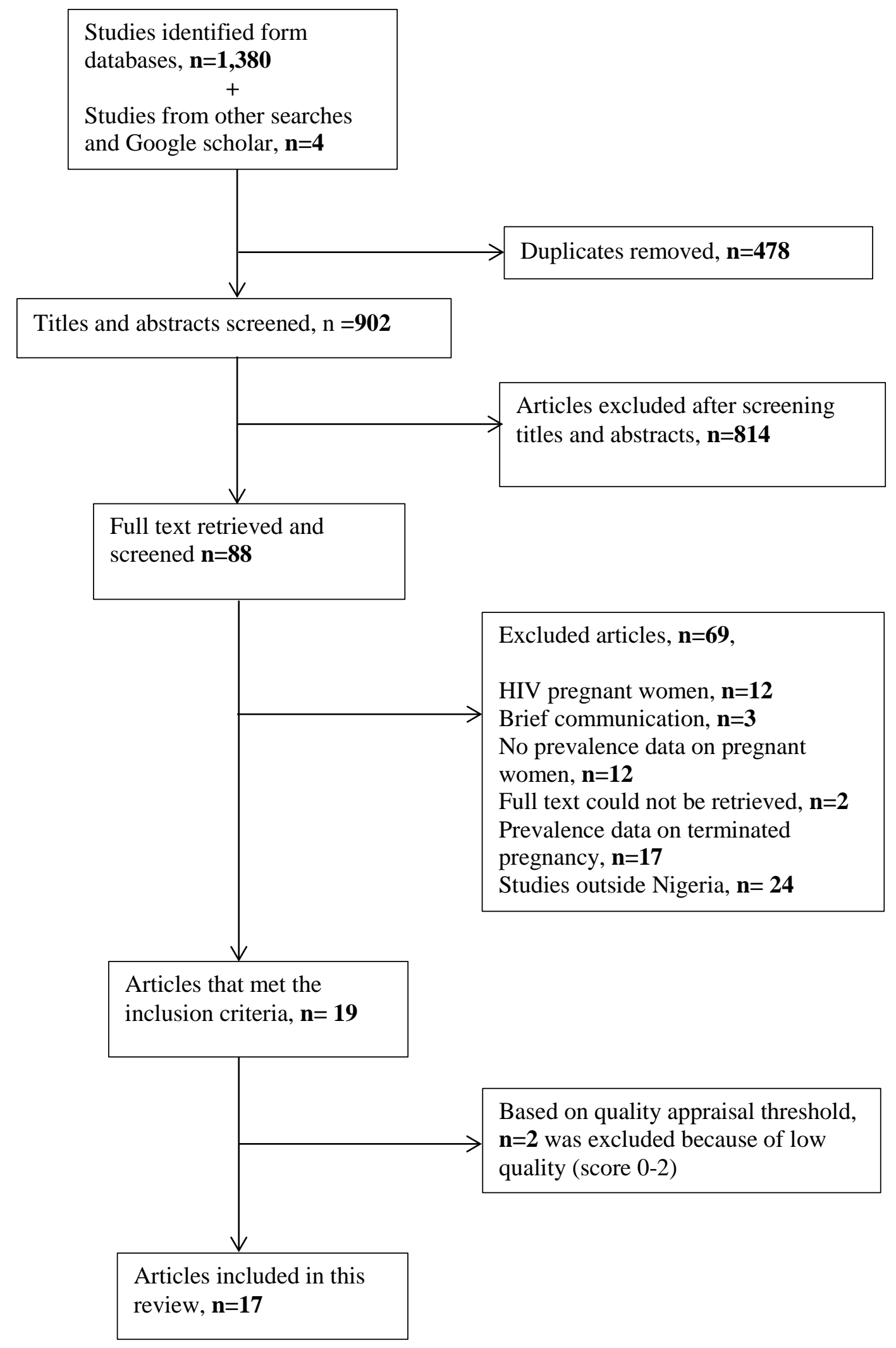




\section{Table 1: Inclusion criteria}

\section{Inclusion criteria}

- Quantitative primary and secondary empirical studies reporting DV prevalence data

- Conducted in Nigeria

- Participants were pregnant women

- Published in English language

- Reported in peer-reviewed sources

- $\quad$ Published between 2004-2016 
Table 2: Quality appraisal of included studies

\begin{tabular}{|c|c|c|c|c|c|c|c|c|c|}
\hline $\begin{array}{l}\text { Authors and } \\
\text { year }\end{array}$ & $\begin{array}{l}\text { Clearly } \\
\text { defined } \\
\text { target } \\
\text { population }\end{array}$ & $\begin{array}{l}\text { Use of } \\
\text { probability } \\
\text { sampling }\end{array}$ & $\begin{array}{l}\text { Respondents } \\
\text { characteristics } \\
\text { match the } \\
\text { target } \\
\text { population }\end{array}$ & $\begin{array}{l}\text { Standardization } \\
\text { of data } \\
\text { collection } \\
\text { method }\end{array}$ & $\begin{array}{l}\text { Survey } \\
\text { instruments } \\
\text { reliable }\end{array}$ & $\begin{array}{l}\text { Survey } \\
\text { instruments } \\
\text { valid }\end{array}$ & $\begin{array}{l}\text { Features of } \\
\text { sampling } \\
\text { design } \\
\text { accounted for } \\
\text { in the analysis }\end{array}$ & $\begin{array}{l}\text { Results } \\
\text { include CI } \\
\text { for statistical } \\
\text { estimates }\end{array}$ & Scores \\
\hline $\begin{array}{l}\text { Abasiubong, } \\
\text { Abasiattai, } \\
\text { Bassey, and } \\
\text { Ogunsemi (2010) }\end{array}$ & $\mathrm{Y}$ & $\bar{Y}$ & $\mathrm{Y}$ & $\bar{Y}$ & $\mathrm{Y}$ & $\bar{Y}$ & $\mathrm{Y}$ & $\mathrm{Y}$ & $\overline{8}$ \\
\hline $\begin{array}{l}\text { Adesina, Oyugbo } \\
\text { and Olubukola } \\
\text { (2011) }\end{array}$ & $\mathrm{Y}$ & $\mathrm{Y}$ & $\mathrm{Y}$ & $\mathrm{N}$ & $\mathrm{N}$ & $\mathrm{Y}$ & $\mathrm{Y}$ & $\mathrm{Y}$ & 6 \\
\hline $\begin{array}{l}\text { Ameh, Shittu, and } \\
\text { Abdul (2009) }\end{array}$ & $\mathrm{Y}$ & $\mathrm{N}$ & $\mathrm{Y}$ & $\mathrm{Y}$ & $\mathrm{N}$ & $\mathrm{Y}$ & $\mathrm{N}$ & $\mathrm{N}$ & 4 \\
\hline $\begin{array}{l}\text { Arulogun and } \\
\text { Jidda (2011) }\end{array}$ & $\mathrm{Y}$ & $\mathrm{Y}$ & $\mathrm{Y}$ & $\mathrm{Y}$ & $\mathrm{Y}$ & $\mathrm{Y}$ & $\mathrm{Y}$ & $\mathrm{N}$ & 7 \\
\hline $\begin{array}{l}\text { Ashimi and Amole } \\
\text { (2015) }\end{array}$ & $\mathrm{Y}$ & $\mathrm{N}$ & $\mathrm{N}$ & $\mathrm{Y}$ & $\mathrm{Y}$ & $\mathrm{Y}$ & $\mathrm{Y}$ & $\mathrm{Y}$ & 6 \\
\hline $\begin{array}{l}\text { Awusi, Okeleke, } \\
\text { and Ayanwu } \\
\text { (2009) }\end{array}$ & $\mathrm{Y}$ & $\mathrm{N}$ & $\mathrm{Y}$ & $\mathrm{N}$ & $\mathrm{Y}$ & $\mathrm{Y}$ & $\mathrm{Y}$ & $\mathrm{N}$ & 5 \\
\hline $\begin{array}{l}\text { Efetie and } \\
\text { Salami (2007) }\end{array}$ & $\mathrm{Y}$ & $\mathrm{N}$ & $\mathrm{Y}$ & $\mathrm{Y}$ & $\mathrm{N}$ & $\mathrm{N}$ & $\mathrm{N}$ & $\mathrm{Y}$ & 4 \\
\hline $\begin{array}{l}\text { Envuladu et al. } \\
\text { (2012) }\end{array}$ & $\mathrm{Y}$ & $\mathrm{N}$ & $\mathrm{N}$ & $\mathrm{N}$ & $\mathrm{N}$ & $\mathrm{Y}$ & $\mathrm{N}$ & $\mathrm{Y}$ & 4 \\
\hline $\begin{array}{l}\text { Ezechi et al. } \\
(2004)\end{array}$ & $\mathrm{Y}$ & $\mathrm{N}$ & $\mathrm{Y}$ & $\mathrm{Y}$ & $\mathrm{Y}$ & $\mathrm{N}$ & $\mathrm{N}$ & $\mathrm{N}$ & 4 \\
\hline
\end{tabular}

$\mathrm{Y}=$ Yes N=No CI=Confidence Interval 
Table 2: Quality appraisal of included studies (continued)

\begin{tabular}{|c|c|c|c|c|c|c|c|c|c|}
\hline Authors and year & $\begin{array}{l}\text { Clearly } \\
\text { defined } \\
\text { target } \\
\text { population }\end{array}$ & $\begin{array}{l}\text { Use of } \\
\text { probability } \\
\text { sampling }\end{array}$ & $\begin{array}{l}\text { Respondents } \\
\text { characteristics } \\
\text { match the target } \\
\text { population }\end{array}$ & $\begin{array}{l}\text { Standardization } \\
\text { of data collection } \\
\text { method }\end{array}$ & $\begin{array}{l}\text { Survey } \\
\text { instruments } \\
\text { reliable }\end{array}$ & $\begin{array}{l}\text { Survey } \\
\text { instruments } \\
\text { valid }\end{array}$ & $\begin{array}{l}\text { Features of } \\
\text { sampling design } \\
\text { accounted for in } \\
\text { the analysis }\end{array}$ & $\begin{array}{l}\text { Results } \\
\text { include CI for } \\
\text { statistical } \\
\text { estimates }\end{array}$ & Score \\
\hline $\begin{array}{l}\text { Fawole, Abass, and } \\
\text { Fawole (2010) }\end{array}$ & $\mathrm{Y}$ & $\mathrm{N}$ & $\mathrm{Y}$ & $\bar{Y}$ & $\mathrm{Y}$ & $\bar{Y}$ & $\mathrm{Y}$ & $\mathrm{N}$ & 8 \\
\hline $\begin{array}{l}\text { Fawole, Hunyinbo } \\
\text { and Fawole (2008) }\end{array}$ & $\mathrm{Y}$ & $\mathrm{Y}$ & $\mathrm{Y}$ & $\mathrm{Y}$ & $\mathrm{N}$ & $\mathrm{Y}$ & $\mathrm{Y}$ & $\mathrm{N}$ & 6 \\
\hline $\begin{array}{l}\text { Gyuse, Ushie, and } \\
\text { Etukidem (2009) }\end{array}$ & $\mathrm{Y}$ & & $\mathrm{Y}$ & $\mathrm{Y}$ & $\mathrm{Y}$ & $\mathrm{Y}$ & $\mathrm{Y}$ & $\mathrm{N}$ & 7 \\
\hline $\begin{array}{l}\text { Iliyasu, Abubakar, } \\
\text { Galadanci, } \\
\text { Hayatu, and Aliyu } \\
\text { (2013) }\end{array}$ & $\mathrm{Y}$ & $\mathrm{Y}$ & $\mathrm{Y}$ & $\mathrm{Y}$ & $\mathrm{Y}$ & $\mathrm{Y}$ & $\mathrm{Y}$ & $\mathrm{Y}$ & 8 \\
\hline Ansari et al. (2016) & $\mathrm{Y}$ & $\mathrm{Y}$ & $\mathrm{Y}$ & $\mathrm{Y}$ & $\mathrm{Y}$ & $\mathrm{Y}$ & $\mathrm{Y}$ & $\mathrm{Y}$ & 8 \\
\hline $\begin{array}{l}\text { Olagbuji } \\
\text { Ezeanochie, } \\
\text { Ande, and Ekaete } \\
\text { (2010) }\end{array}$ & $\mathrm{Y}$ & $\mathrm{N}$ & $\mathrm{Y}$ & $\mathrm{Y}$ & $\mathrm{Y}$ & $\mathrm{Y}$ & $\mathrm{Y}$ & & 7 \\
\hline Onoh et al.(2013) & $\mathrm{Y}$ & $\mathrm{N}$ & $\mathrm{Y}$ & $\mathrm{Y}$ & $\mathrm{Y}$ & $\mathrm{Y}$ & $\mathrm{Y}$ & $\mathrm{Y}$ & 7 \\
\hline $\begin{array}{l}\text { Umeora Dimejesi, } \\
\text { Ejikeme, and } \\
\text { Egwuatu (2008) }\end{array}$ & $\mathrm{Y}$ & $\mathrm{Y}$ & $\mathrm{Y}$ & $\mathrm{Y}$ & $\mathrm{Y}$ & $\mathrm{Y}$ & $\mathrm{Y}$ & $\mathrm{Y}$ & 8 \\
\hline Ameh et al. (2008) & $\mathrm{Y}$ & & $\mathrm{N}$ & $\mathrm{Y}$ & $\mathrm{N}$ & $\mathrm{N}$ & $\mathrm{N}$ & $\mathrm{N}$ & 2 \\
\hline $\begin{array}{l}\text { Ameh and Abdul } \\
\text { (2004) }\end{array}$ & $\mathrm{Y}$ & $\mathrm{N}$ & $Y$ & $\mathrm{~N}$ & $\mathrm{~N}$ & $\mathrm{~N}$ & $\mathrm{~N}$ & $\mathrm{~N}$ & 2 \\
\hline
\end{tabular}

$\mathrm{Y}=$ Yes $\mathrm{N}=\mathrm{No} \mathrm{CI}=$ Confidence Interval 
Table 3: Summary of study characteristics and findings

\begin{tabular}{|c|c|c|c|c|c|c|c|}
\hline $\begin{array}{l}\text { Author(s) } \\
\text { and year }\end{array}$ & Study aim & $\begin{array}{l}\text { Study } \\
\text { design }\end{array}$ & $\begin{array}{l}\text { Study setting and } \\
\text { duration }\end{array}$ & Sample size & $\begin{array}{l}\text { Data collection } \\
\text { method }\end{array}$ & Prevalence of DV & $\begin{array}{l}\text { Perpetrators } \\
\text { of DV }\end{array}$ \\
\hline $\begin{array}{l}\text { Abasiubong } \\
\text { et al. } \\
(2010)\end{array}$ & $\begin{array}{l}\text { To measure the } \\
\text { prevalence and identify } \\
\text { the demographic risk } \\
\text { factors for violence } \\
\text { among pregnant women }\end{array}$ & Not stated & $\begin{array}{l}\text { Maternity Unit of } \\
\text { University of Uyo } \\
\text { Teaching Hospital } \\
\text { between October and } \\
\text { December, } 2008\end{array}$ & $\begin{array}{l}236 \text { pregnant } \\
\text { women }\end{array}$ & $\begin{array}{l}\text { Semi-structured } \\
\text { socio-demographic } \\
\text { questionnaire }\end{array}$ & $\begin{array}{l}22.9 \% \text { in index } \\
\text { pregnancy and } 33.1 \% \\
\text { for lifetime prevalence }\end{array}$ & $\begin{array}{l}\text { Husbands, former } \\
\text { husband, boyfriend }\end{array}$ \\
\hline $\begin{array}{l}\text { Arulogun } \\
\text { and Jidda } \\
\text { (2011) }\end{array}$ & $\begin{array}{l}\text { To assess the } \\
\text { experiences, } \\
\text { perpetrators, types, } \\
\text { health seeking } \\
\text { behavior and coping } \\
\text { strategies among } \\
\text { pregnant women exposed } \\
\text { to violence }\end{array}$ & $\begin{array}{l}\text { Cross- } \\
\text { sectional }\end{array}$ & $\begin{array}{l}6 \text { private and public } \\
\text { hospitals in } 3 \text { local } \\
\text { government areas in } \\
\text { Abuja, the Federal } \\
\text { Capital Territory of the } \\
\text { Nigeria, Not stated }\end{array}$ & $\begin{array}{l}300 \text { pregnant } \\
\text { women attending } \\
\text { antenatal services } \\
\text { in public and } \\
\text { private health } \\
\text { facilities }\end{array}$ & $\begin{array}{l}\text { Pretested structured } \\
\text { questionnaire }\end{array}$ & $\begin{array}{l}\text { 15\% in current } \\
\text { pregnancy and } 431.0 \% \\
\text { for lifetime prevalence }\end{array}$ & $\begin{array}{l}\text { Husbands, partners, } \\
\text { husband's relatives }\end{array}$ \\
\hline $\begin{array}{l}\text { Adesina et } \\
\text { al. (2011) }\end{array}$ & $\begin{array}{l}\text { To measure the pattern } \\
\text { and prevalence of } \\
\text { violence against pregnant } \\
\text { women }\end{array}$ & $\begin{array}{l}\text { Cross- } \\
\text { sectional }\end{array}$ & $\begin{array}{l}\text { Antenatal clinic at } \\
\text { University college } \\
\text { hospital (UCH) and } \\
\text { Adeoye maternity } \\
\text { (AM), Ibadan South- } \\
\text { West between } 1 \text { and } 31 \\
\text { March } 2007\end{array}$ & $\begin{array}{l}404 \text { pregnant } \\
\text { women, } 156 \text { from } \\
\text { UCH and } \\
248 \text { from AM }\end{array}$ & $\begin{array}{l}\text { Interviewer } \\
\text { administered } \\
\text { questionnaire }\end{array}$ & $\begin{array}{l}17.1 \% \text { during } \\
\text { pregnancy and } 52 \% \text { for } \\
\text { lifetime prevalence }\end{array}$ & Intimate partner \\
\hline $\begin{array}{l}\text { Ameh et al. } \\
\text { (2009) }\end{array}$ & $\begin{array}{l}\text { To assess the prevalence } \\
\text { of DV and its association } \\
\text { with adverse obstetric } \\
\text { outcomes in pregnant } \\
\text { women }\end{array}$ & $\begin{array}{l}\text { Cross- } \\
\text { sectional }\end{array}$ & $\begin{array}{l}\text { Ahmadu Bello } \\
\text { University Teaching } \\
\text { Hospital, Zaria, Nigeria, } \\
\text { between June to August } \\
2003\end{array}$ & $\begin{array}{l}310 \text { pregnant } \\
\text { women }\end{array}$ & $\begin{array}{l}\text { Structured } \\
\text { questionnaires }\end{array}$ & $\begin{array}{l}28.4 \% \text { in index } \\
\text { pregnancy }\end{array}$ & $\begin{array}{l}\text { Husbands, mother in- } \\
\text { laws, neighbors and } \\
\text { co-mates }\end{array}$ \\
\hline $\begin{array}{l}\text { Ansari et } \\
\text { al. (2016) }\end{array}$ & $\begin{array}{l}\text { To examine the risk } \\
\text { factors and frequency of } \\
\text { physical IPV during } \\
\text { pregnancy }\end{array}$ & Survey & $\begin{array}{l}\text { Household survey, July- } \\
\text { September } 2011\end{array}$ & $\begin{array}{l}7888 \text { (Cross River) } \\
\text { and } 7521 \text { (Bauchi) } \\
\text { women }\end{array}$ & $\begin{array}{l}\text { Questionnaires and } \\
\text { interviews }\end{array}$ & $\begin{array}{l}\text { 22\% (Cross River) and } \\
9 \% \text { (Bauchi) in last } \\
\text { pregnancy }\end{array}$ & Not stated \\
\hline
\end{tabular}


Table 3: Summary of study characteristics and findings (continued)

\begin{tabular}{|c|c|c|c|c|c|c|c|}
\hline $\begin{array}{l}\text { Author(s) and } \\
\text { year }\end{array}$ & Study aim & $\begin{array}{l}\text { Study } \\
\text { design }\end{array}$ & $\begin{array}{l}\text { Study setting and } \\
\text { duration }\end{array}$ & Sample size & $\begin{array}{l}\text { Data } \\
\text { collection } \\
\text { method }\end{array}$ & Prevalence of DV & $\begin{array}{l}\text { Perpetrators } \\
\text { of DV }\end{array}$ \\
\hline $\begin{array}{l}\text { Ashimi and } \\
\text { Amole (2015) }\end{array}$ & $\begin{array}{l}\text { To determine the } \\
\text { prevalence and } \\
\text { predictors of DV among } \\
\text { pregnant women }\end{array}$ & $\begin{array}{l}\text { Descriptive } \\
\text { cross- } \\
\text { sectional }\end{array}$ & $\begin{array}{l}\text { Antenatal clinic of a } \\
\text { health facility in Birnin- } \\
\text { kudu }\end{array}$ & 326 pregnant women & $\begin{array}{l}\text { Structured } \\
\text { interviewer } \\
\text { administered } \\
\text { questionnaire }\end{array}$ & $\begin{array}{l}\text { 34.3\% during } \\
\text { pregnancy }\end{array}$ & $\begin{array}{l}\text { Husbands, co- } \\
\text { wives }\end{array}$ \\
\hline $\begin{array}{l}\text { Awusi et al. } \\
(2009)\end{array}$ & $\begin{array}{l}\text { To document the } \\
\text { knowledge, prevalence } \\
\text { and perception of DV } \\
\text { among pregnant women }\end{array}$ & $\begin{array}{l}\text { Cross - } \\
\text { sectional }\end{array}$ & $\begin{array}{l}\text { Antenatal clinic of Central } \\
\text { Hospital, Oleh,Isoko, } \\
\text { Delta State, between 1st } \\
\text { February } 2008 \text { to 3rd } \\
\text { January }\end{array}$ & $\begin{array}{l}400 \text { pregnant women } \\
\text { attending antenatal } \\
\text { clinic }\end{array}$ & $\begin{array}{l}\text { Pretested } \\
\text { structured } \\
\text { questionnaire }\end{array}$ & $36 \%$ during pregnancy & Intimate partners \\
\hline $\begin{array}{l}\text { Efetie and } \\
\text { Salami (2008) }\end{array}$ & $\begin{array}{l}\text { To determine the } \\
\text { perception, prevalence } \\
\text { and knowledge of DV } \\
\text { among pregnant women }\end{array}$ & $\begin{array}{l}\text { Cross- } \\
\text { sectional }\end{array}$ & $\begin{array}{l}\text { National Hospital } \\
\text { Abuja, Nigeria, } \\
\text { between May to July } \\
2005\end{array}$ & 334 pregnant women & Questionnaire & $\begin{array}{l}\text { Lifetime } \\
\text { prevalence rate } \\
\text { was } 37.4 \%\end{array}$ & $\begin{array}{l}\text { Husbands/spouse, } \\
\text { in-laws, wife's } \\
\text { relations, } \\
\text { neighbors, } \\
\text { boyfriends, friends }\end{array}$ \\
\hline $\begin{array}{l}\text { Envuladu et al. } \\
\text { (2012) }\end{array}$ & $\begin{array}{l}\text { To determine the } \\
\text { prevalence, pattern and } \\
\text { factors associated with } \\
\text { DV among pregnant } \\
\text { women }\end{array}$ & $\begin{array}{l}\text { Descriptive } \\
\text { cross- } \\
\text { sectional }\end{array}$ & $\begin{array}{l}\text { Primary Healthcare } \\
\text { center, Jos, Plateau, } \\
\text { Nigeria for } 4 \text { weeks }\end{array}$ & 202 pregnant women & $\begin{array}{l}\text { Semi- } \\
\text { structured } \\
\text { interviewer } \\
\text { questionnaire }\end{array}$ & $\begin{array}{l}31.8 \% \text { in index } \\
\text { pregnancy and } 28.9 \% \\
\text { in previous pregnancy }\end{array}$ & Not stated \\
\hline $\begin{array}{l}\text { Ezechi et al. } \\
(2004)\end{array}$ & $\begin{array}{l}\text { To explore the patterns } \\
\text { and prevalence of DV in } \\
\text { pregnant women }\end{array}$ & Not stated & $\begin{array}{l}\text { Havana hospital and Felin } \\
\text { hospital, Lagos; January } \\
\text { and June } 2003\end{array}$ & 522 pregnant women & $\begin{array}{l}\text { Structured } \\
\text { questionnaires }\end{array}$ & $\begin{array}{l}\text { 8.7\% in current } \\
\text { pregnancy and } 47.1 \% \\
\text { for lifetime prevalence }\end{array}$ & $\begin{array}{l}\text { Husbands and } \\
\text { boyfriends, in- } \\
\text { laws and relations }\end{array}$ \\
\hline $\begin{array}{l}\text { Fawole et al. } \\
\text { (2010) }\end{array}$ & $\begin{array}{l}\text { To explore the } \\
\text { prevalence and patterns } \\
\text { of DV among pregnant } \\
\text { women }\end{array}$ & Not stated & $\begin{array}{l}\text { Adeoye maternity } \\
\text { Hospital and Ring Road, } \\
\text { State Hospital, Ibadan; } \\
\text { May and June } 2004\end{array}$ & 534 pregnant women & $\begin{array}{l}\text { Structured } \\
\text { questionnaires }\end{array}$ & $\begin{array}{l}31.8 \% \text { in index } \\
\text { pregnancy }\end{array}$ & Partners, relatives \\
\hline
\end{tabular}


Table 3: Summary of study characteristics and findings (continued)

\begin{tabular}{|c|c|c|c|c|c|c|c|}
\hline $\begin{array}{l}\text { Author(s) } \\
\text { and year }\end{array}$ & Study aims and objectives & $\begin{array}{l}\text { Study } \\
\text { design }\end{array}$ & $\begin{array}{l}\text { Study setting and } \\
\text { duration }\end{array}$ & Sample size & $\begin{array}{l}\text { Data collection } \\
\text { method }\end{array}$ & Prevalence of DV & $\begin{array}{l}\text { Perpetrators } \\
\text { of DV }\end{array}$ \\
\hline $\begin{array}{l}\text { Fawole et al. } \\
\text { (2008) }\end{array}$ & $\begin{array}{l}\text { To determine the risk and } \\
\text { prevalence of violence against } \\
\text { pregnant women }\end{array}$ & $\begin{array}{l}\text { Cross- } \\
\text { sectional }\end{array}$ & $\begin{array}{l}3 \text { health facilities in } \\
\text { Abeokuta south, Ogun } \\
\text { State, between } \\
\text { September and } \\
\text { November } 2003\end{array}$ & 534 pregnant women & $\begin{array}{l}\text { Semi-structured } \\
\text { interviewer } \\
\text { questionnaire }\end{array}$ & $\begin{array}{l}2.3 \% \text { during index } \\
\text { pregnancy and } 14.2 \% \text { a } \\
\text { year before index } \\
\text { pregnancy }\end{array}$ & $\begin{array}{l}\text { Husband, } \\
\text { mother, father, } \\
\text { relative, sister } \\
\text { boyfriend }\end{array}$ \\
\hline $\begin{array}{l}\text { Gyuse et al. } \\
\text { (2009) }\end{array}$ & $\begin{array}{l}\text { To establish the prevalence of } \\
\text { DV among pregnant women }\end{array}$ & $\begin{array}{l}\text { Descriptive } \\
\text { cross- } \\
\text { sectional }\end{array}$ & $\begin{array}{l}\text { Antenatal clinic of } \\
\text { ECWA Evangel } \\
\text { Hospital for 6months }\end{array}$ & $\begin{array}{l}340 \text { antenatal attendees } \\
\text { at an antenatal clinic }\end{array}$ & Questionnaires & $\begin{array}{l}12.6 \% \text { in current } \\
\text { pregnancy and } \\
63.2 \% \text { for lifetime } \\
\text { prevalence }\end{array}$ & Not stated \\
\hline $\begin{array}{l}\text { Iliyasu et al. } \\
\text { (2013) }\end{array}$ & $\begin{array}{l}\text { To estimate the prevalence and } \\
\text { identify the socio-demographic } \\
\text { risk factors of violence among } \\
\text { pregnant }\end{array}$ & $\begin{array}{l}\text { Cross- } \\
\text { sectional }\end{array}$ & $\begin{array}{l}\text { Aminu Kano Teaching } \\
\text { Hospital, Kano, } \\
\text { between June and July } \\
2011\end{array}$ & 400 pregnant women & $\begin{array}{l}\text { Pretested } \\
\text { structured } \\
\text { interviewer } \\
\text { administered } \\
\text { questionnaire }\end{array}$ & $\begin{array}{l}7.4 \% \text { in current } \\
\text { pregnancy }\end{array}$ & $\begin{array}{l}\text { Husbands, co- } \\
\text { wives, stepsons }\end{array}$ \\
\hline $\begin{array}{l}\text { Olagbuji et } \\
\text { al. (2010) }\end{array}$ & $\begin{array}{l}\text { To identify the pattern and } \\
\text { relationship between pregnancy } \\
\text { and DV }\end{array}$ & $\begin{array}{l}\text { Cross- } \\
\text { sectional }\end{array}$ & $\begin{array}{l}\text { University of Benin } \\
\text { Teaching Hospital, } \\
\text { Benin City, between } \\
\text { December } 2008 \text { to April } \\
2009\end{array}$ & $\begin{array}{l}502 \text { obstetric patients } \\
\text { women attending a } 6 \text { th } \\
\text { week post-natal clinic }\end{array}$ & $\begin{array}{l}\text { Semi-structured } \\
\text { questionnaire }\end{array}$ & $\begin{array}{l}28.3 \% \text { during current } \\
\text { pregnancy and } 43.5 \% \text { a } \\
\text { year before current } \\
\text { pregnancy }\end{array}$ & $\begin{array}{l}\text { Spouse, mother } \\
\text { in-law, } \\
\text { relatives of } \\
\text { spouse, } \\
\text { neighbors }\end{array}$ \\
\hline $\begin{array}{l}\text { Onoh et } \\
\text { al.(2013) }\end{array}$ & $\begin{array}{l}\text { To determine the pattern, } \\
\text { prevalence and consequences of } \\
\text { IPV during pregnancy }\end{array}$ & $\begin{array}{l}\text { Cross- } \\
\text { sectional }\end{array}$ & $\begin{array}{l}\text { Antenatal clinics of } \\
\text { Federal medical Centre, } \\
\text { Abakaliki; Ebonyi state, } \\
\text { April and June } 2011\end{array}$ & $\begin{array}{l}350 \text { pregnant women } \\
\text { but only } 321 \text { pregnant } \\
\text { women at an } \\
\text { antenatal clinic }\end{array}$ & $\begin{array}{l}\text { Pre-tested semi- } \\
\text { structured } \\
\text { questionnaire }\end{array}$ & $\begin{array}{l}44.6 \% \text { in the index } \\
\text { pregnancy }\end{array}$ & Not clear \\
\hline $\begin{array}{l}\text { Umeora et } \\
\text { al. (2008) }\end{array}$ & $\begin{array}{l}\text { To evaluate patterns, } \\
\text { prevalence and determinants of } \\
\text { DV among prenatal clinic } \\
\text { attendees }\end{array}$ & $\begin{array}{l}\text { Cross- } \\
\text { sectional }\end{array}$ & $\begin{array}{l}\text { Ebonyi State } \\
\text { University Teaching } \\
\text { Hospital, Abakaliki, } \\
\text { Nigeria; March and } \\
\text { May 2005 }\end{array}$ & $\begin{array}{l}500 \text { pregnant women } \\
\text { attending s prenatal } \\
\text { care hospital }\end{array}$ & $\begin{array}{l}\text { Standardized } \\
\text { questionnaire }\end{array}$ & 13.6\% during pregnancy & Not stated \\
\hline
\end{tabular}


Table 4: Types of abuse

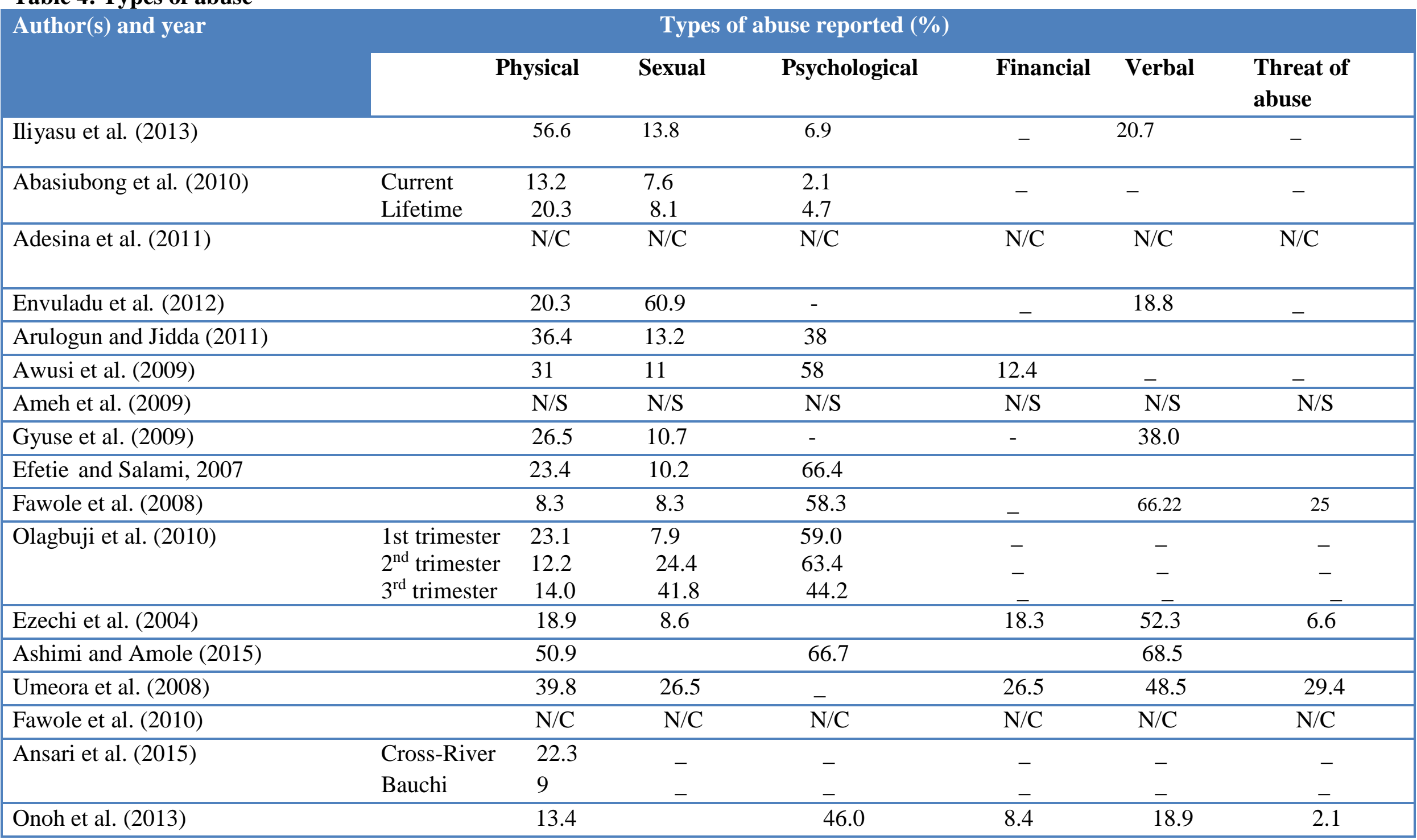


Note: N/C= Not Clear. N/S=Not Stated. $(-)=$ Not Reported 
